\title{
HEALTH, WELFARE AND EFFICIENCY OF THE WORKER
}

\section{$\mathrm{T}$}

HE first conference of the British Occupational Hygiene Society was held at the London School of Hygiene and Tropical Medicine on November 2. The conference was opened by the Minister of Labour and National Service, Sir Walter Monckton, who said that provision for occupational health in the widest sense is increasingly concerning the Government. The human element, in industry is vital for productivity and, while the primary aim of industrial research is understandably concerned with discovering new and improved methods of production, it must not overlook hygiene and safety factors. The Society, continued Sir Walter, has valuable work to do in bringing together the physician, the medical scientist and the psychologist, who study man, and the physical scientist, chemist and engineer, who study his environment.

In his presidential address, Dr. T. Bedford outlined the development of occupational hygiene in Great Britain, which has grown from a wish to protect young persons and women from the evils of gross overwork some one hundred and fifty years ago. Safety and concern with industrial poisoning date back about ninety years, and the progress made is due to the initiative and devotion of the Factory Inspectorate. It was not until the First World War that concern with productivity, vital for success, resulted in the formation of the Health of Munition Workers Committee, on behalf of which many investigations were undertaken. Since then, various government establishments have worked in the field, and some university departments have also been interested. Further impetus resulted from the Second World War, both in connexion with war industries and with the fighting services.

Dr. Bedford said that occupational hygiene deals with the prevention of disease due to industrial materials and also with the effects of the working environment. The application of physiological and anatomical principles to the design of machines, the arrangement of industrial tasks and psychological factors, such as fatigue and maladjustment of the worker to his vocation or working group, are likewise included. It is to bo hoped that the Society will make contributions to all these fields of knowledge.

There are grave deficiencies in the postgraduate medical training available in Britain for medical practitioners who wish to work in industry, and the instruction in methods of measuring and controlling the worker's environment is inadequate. No university in Britain offers a full course for engineers and other non-medical graduates on the lines of those which have been so successful in the United States. This seemed to Dr. Bedford to be a serious lack.

Mr. S. A. Roach, of the Medical Research Council's Pneumoconiosis Research Unit, gave a paper on "Measuring the Worker's Environment", which dealt with pneumoconiosis in the coal industry that is caused by the inhalation of coal dust over a long period. The quantity of dust inhaled is expressed in particle-years per c.c. (sizes between 0.5 and 5 microns), and Mr. Roach claimed that, when this figure was less than 4,000, no $X$-ray abnormalities were detectable in the sixty colliers who were examined. Fifty per cent abnormalities occurred at more than 24,000 particle - years per c.c.
Dr. D. G. Harvey, of the Medical Research Council's Department for Research in Industrial Medicine, then gave his paper on "Problems of Chemical Toxicity". Pointing out that environmental studies in a chemical industry are often not made until after an accident has occurred, Dr. Harvey made a plea for the investigation of toxic risks before a new substance is used in production. In the determination of atmospheric concentrations, it is not enough to take a few 'grab' samples; mass concentration values over a good length of time, say, one day or a working shift, are essential. Routine determinations of blood and urine levels of a toxic substance give indications of the minimum amount present in the body and are useful for monitoring workers. The elimination-rate can also be found from these observations by removing a man from exposure.

Animal experiments are valuable, continued Dr. Harvey, because, by administering repeated small doses, accumulation in the body can be demonstrated; substances which act like this are particularly dangerous to human beings exposed to chronic intoxication. Quantitative biochemical species differentiation has to be watched for, however, for man is notably inefficient in detoxicating poisons. Thus, initial blood-levels of $60-80 \mu \mathrm{gm}$. of 3:5-dinitro$o$-cresol per gm. are reduced to insignificant amounts in two days in the rabbit, eight days in the rat but forty days in man.

The final speaker was Mr. J. S. Braham, engineering controller of Imperial Chemical Industries, Ltd., who pointed out that, with the industrial capital investment in Great Britain now exceeding $£ 1,000$ million a year, the industrial designer is faced with many and complex problems. The potential savings in capital and production cost to be derived from good design are considerable, and the creation of a new plant or factory is a matter for many people who represent the various technical and commercial interests involved. Outlining the principal stages in the growth of a project, Mr. Braham emphasized that the requirements of hygiene ought to be considered in each to some degree and, at certain crucial stages, very closely. Those who are responsible for hygiene cannot be in touch with research, development and design too early. This early contact is very important because hygiene is not a primary consideration of scientific workers engaged in creating a new manufacturing process.

The ensuring of the necessary close co-operation between the industrial hygienist and the designer is a problem of organization and of procedures calculated to bring all the relevant factors under the notice of the proper people at the proper time. 'This Mr. Braham proposed to facilitate by preparing a special list of all issues of hygiene for routine use as an aide-memoire. He also suggested the keeping of a record or history sheet for a project on which would be detailed the consultation of all interests and the implementation of the decisions taken.

Mr. Braham thought that working conditions in British factories are steadily being improved, though some remaining black spots have to be removed. The provision of healthy, safe and agreeable conditions for those who work in them is a moral obligation; it is also an economic necessity for 
maximum productivity upon which the prosperity of all depend.

The conference will be reported in full in the January issue of the British Journal of Industrial Medicine. The Society is arranging another conference at the London School of Hygiene and Tropical Medicine, on April 6, 1954, when the subject will be on the maximum allowable concentrations of toxic and dangerous air contaminants.

\section{N. Davres}

\section{INTERNATIONAL SCIENTIFIC FILM ASSOCIATION}

\section{ANNUAL CONGRESS IN LONDON}

$\mathrm{T}$

HE seventh annual congress of the International Scientific Film Association was held during September 18-26 in London on the South Bank, the meetings of the general assembly and specialized groups being in the Royal Festival Hall and the afternoon and evening scientific film shows being in the National Film Theatre. More than one hundred delegates and observers from twenty-two countries and from international bodies (such as Unesco) attended, together with a large number of visitors. At the various sessions more than two hundred and twenty films were shown from twenty-four countries, including some seventy medical films. During the congress Canada and Morocco were made members of the Association.

The congress was opened at the gala première film show on the evening of September 18 by Sir Walter Monckton, Minister of Labour and National Service, who paid tribute to the Scientific Film Association of Great Britain for its work in organizing the congress and for its services to industry generally. The films shown at this performance included contributions from India ("National Physical Laboratory"), Great Britain ("The Desert Locust"; World Wide Pictures, Ltd.), Hungary ("Blossom Time till Autumn Frost"; a remarkable Nature film by HomokiNagy), Australia ("Pre-stressed Concrete Tower"), Canada ("Embryonic Development-the Chick"; J. V. Durden), Belgium ("Combat avec l'Ombre"), U.S.S.R. ("Life in the Arctic"; Moscow Popular Science Film Studio, directed by A. Zguridi) and France ("Flammes du Soleil"; Paris Observatory, produced by Jean Painlevé and directed by Joseph Leclerc).

The next day the general assembly met, appointed working committees and transacted the internal business of the Association, adopting the honorary secretary's report and the balance sheet. The congress then divided into its various specialized groups which held meetings during the following six days.

The Research Group held four meetings, two of which were jointly with the Medical and Industrial Groups, respectively. Its first meeting was on the morning of September 20, when three films of research interest were shown and discussed. The first, "Growth of Crystals" (France; Jean Dragescu), used time-lapse and polarized-light techniques to study the crystallization of various stable and unstable substances. The second, "Waters of Coweeta" (United States), was an impressive record of forestry research based on the long-term analysis and measurement of the run-off from watersheds under different conditions. The third, "Biology of the Hamster" (Western Germany; Dr. Gotthard Wolf), was part of a German plan to make an encyclopædia of film and was a complete record of one animal's behaviour during a typical chain of circumstances.

The second research session, jointly with the Industrial Group, was on September 22, when the main subject was "High Speed Films in Industrial Research". There were five contributions-two French and three British. M. Galey, of the Institut de Recherches de la Sidérurgie, showed a film used for investigating the interior of a Martin furnace; it was interesting to compare this with the British contribution by Mr. C. Burns (British Iron and Steel Research Association), who showed a three-dimensional film made to investigate the movements of air and coke particles inside a blast furnace. The technique used enabled actual measurements of high accuracy to be made of the size and shape of the cavity caused by the air blast, and provided a good example of the way films can be used to investigate subjects which cannot be explored by other methods. Mr. John Rogers (Building Research Station) read a paper, illustrated by film, on the uses of the film in building research, which included an interesting description of the use of films in investigating problems of fluid flow. There were a French and a British contribution illustrating railway research : M. Censier, chief of the cinema service of the French national railways, introduced a film showing the use of the high-speed camera on the French railways to investigate speed and wear tests; and Mr. J. C. Lucas (Railway Executive Research Department) showed a film made to investigate a condition of rail wear on electric tracks known as 'periodic side-cutting'.

The third session, on September 23, with Dr. G. Wolf presiding, was a joint meeting with the Medical Group to discuss image converter techniques. Papers were read by Dr. J. S. Courtney-Pratt (University of Cambridge) on the use of image converter tubes in high-speed photography, Mr. A. E. Sarson (Marconi, Ltd.) on the application of television to cinematography and Dr. W. J. Oosterkamp (Philips, Netherlands) on a new X-ray intensifier.

The final research session was on September 26, at the Shell Film Unit, under the chairmanship of Dr. J. Frédéric (Belgium). Ten films were shown andvery briefly-discussed. They included M. R. G. Busnel (France) introducing a film "Enregistrements par une technique electro-accoustique de movements de faible amplitude : applications à la physiologie et la pharmaco-dynamie", which depicted the measurement of small pulsations (beating of a frog's heart, blood vessels in a mouse's foot, etc.) by an apparatus devised by Busnel and Pasquinelly, and amplified and recorded by an oscillograph. Dr. Frédéric showed his film "Recherche experimentale de Chondriome", investigating and recording movements of mitochrondria when treated with various reagents. Dr. W. Rogers (East Malling) presented "The Freezing of Plant Tissues", which attracted great interest and applause.

Other events during the congress were a wellplanned series of industrial sessions, covering the use of films on vocational guidance, training of personnel, motion study and industrial welfare; a conference on the dissemination of science by television, under the chairmanship of Mrs. Mary Adams; a morning session on education addressed by Dr. J. Harrison (Educational Foundation for Visual Aids) and Dr. 